\author{
E.M. Ebomah ${ }^{1}$, U.O. Ugbomhe ${ }^{2}$ \\ ${ }^{1}$ Rehoboth C-Becal Research \& Development Centre, Nigeria \\ ${ }^{2}$ Ambrose Alli University, Ekpoma, Edo State, Nigeria, e-mail: ugbomhe2017@gmail.com
}

\title{
CROSS BORDER INVESTMENT INFLOW IN PALM OIL INDUSTRY IN NIGERIA: KEY SUCCESS FACTORS
}

The study examined cross border investment inflow in palm oil industry in Nigeria. It focused on the key success factors for cross border investments inflow. Descriptive survey design method was adopted in carrying out the study while Pearson Product Moment Correction statistical tool was used in estimating the parameter of relationship between the regressor and regressand variables of the study. The key success factors that were subjected to empirical test proved positively significant to palm oil investment inflow at the $r$ values of $0.745,0.729,0.796,0.652,0.536,0.866,0.598$, $0.705,0.720$ and 0.35 . These analysis results suggested that market size, product demand size, return on investment, propensity to gross domestic product and foreign exchange earnings, first mover advantage, palm oil by-product potentials, availability of labour and effective labour cost, policy on land use, government policy measures on economic diversification and risk-free operational environment are critical to investment inflow in the palm oil industry. Based on these findings, the study recommends that to harness the vast opportunities in the palm oil industry like other counterpart nations that are at the forefront in the global palm oil production, government should gear its efforts towards having sustainable investment policy framework in this new strategic business area, provide enabling environment and conditions to boost local ad cross border business development in the industry.

Key words: Cross Border Investment (CBI), Key Success Factors (KSF), Palm Oil Industry.

\author{
Э.М. Эбома ${ }^{1}$, У.О. Угбомхе \\ 'Rehoboth C-Becal ғылыми-зерттеу орталығы, Нигерия \\ ${ }^{2}$ Амброуз Амли университеті, Экпома, ЭАо штаты, Нигерия, e-mail: ugbomhe2017@gmail.com

\section{Нигериядағы пальма майы саласына трансшекарамық инвестициямар: табыстылықтың негізгі фракторлары}

Зерттеу Нигериядағы пальма майы саласына инвестициялардың трансшекаралық ағындарын қарастырады. Трансшекаралық инвестициялар ағынының негізгі табыстылық фракторларына назар аударылды. Зерттеу барысында сипаттамалық зерттеу әдісі қолданы^ды, ал регрессор мен түсіндіруші айнымалылар арасындағы байланыс параметрін бағалау үшін Pearson Product Moment Correction статистикалық құралы пайдаланылды. Эмпирикалық бағалау табыстылықтың негізгі факторлары пальма майы саласына инвестициялардың r 0.745, 0.729, $0.796,0.652,0.536,0.866,0.598,0.705,0.720$ және 0.35 оң мәнділігін көрсетті. Бұл талдау нәтижелері көрсеткендей, нарық көлемі, өнімге сұраныс, инвестицияның қайтарымы, ішкі өнімнің бейімділігі және валюта бағамдары, бірінші кезектегі артықшылық, пальма майының жанама өнімі, жұмыс күші мен тиімді жұмыс шығындары, жерді пайдалану саясаты, Пальма майы өнеркәсібіне инвестициялар ағынында экономиканы әртараптандыру және тәуекелсіз жұмыс ортасы жөніндегі мемлекеттік саясат шаралары өте маңызды. Осы нәтижелерге сүйене отырып, зерттеу пальма майы өнеркәсібіндегі кең мүмкіндіктерді пайдалануға кеңес береді, өйткені басқа серіктес елдер пальма майын өндірудің жаһандық, деңгейінің басында тұр, үкімет осы жаңа стратегияда тұрақты инвестициялық, саясат негізін құруға назар аударуы керек, атап айтқанда, салада жергілікті және трансшекаралық бизнесті дамытуды жеделдету үшін қолайлы жағдайлар жасау.

Түйін сөздер: трансшекаралық инвестициялар, табыстылықтың негізгі факторлары, пальма майы саласы. 


\author{
Э.М. Эбома ${ }^{1}$, У.О. Угбомхе ${ }^{2}$ \\ 'Центр исследований и разработок Rehoboth C-Becal, Нигерия \\ 2Университет Амброуза Амли, Нигерия, Экпома, штат ЭАо, e-mail: ugbomhe2017@gmail.com
}

Приток трансграничных инвестиций в инАустрию пальмового масла в Нигерии: ключевые факторы успеха

\begin{abstract}
В исследовании рассматривается трансграничный приток инвестиций в отрасль пальмового масла в Нигерии. Основное внимание уделялось ключевым фракторам успеха притока трансграничных инвестиций. При проведении исследования был использован метод проведения описательного опроса, а при оценке параметра взаимосвязи между регрессором и объясняющими переменными использовался статистический инструмент Pearson Product Moment Correction. К^ючевые факторы успеха, которые были подвергнуты эмпирической проверке, оказались положительно значимыми Аля притока инвестиций в пальмовое масло при значениях r 0,745, 0,729, 0,796, 0,652, 0,536, 0,866, 0,598, 0,705, 0,720 и 0,35. Эти результаты анализа показали, что размер рынка, размер спроса на продукцию, рентабельность инвестиций, ск^онность к валовому внутреннему продукту и валютная выручка, преимущество первопроходца, потенциал побочного продукта пальмового масла, доступность рабочей силы и эффективные затраты на рабочую силу, политика в области землепользования, меры государственной политики по диверсификации экономики и безрисковой операционной среде имеют решающее значение Аля притока инвестиций в отрасль пальмового масла. Исходя из этих выводов, в исследовании рекомендуется использовать широкие возможности в отрасли производства пальмового масла, как и в других странах-партнерах, которые находятся на переднем крае мирового производства пальмового масла, правительство Аолжно направить свои усилия на созАание устойчивой основы инвестиционной политики в этой новой стратегии, в частности создание благоприятных условий и условий Аля ускорения развития местного и трансграничного бизнеса в отрасли.
\end{abstract}

Ключевые слова: трансграничные инвестиции, ключевые факторы успеха, отрасль пальмового масла.

\section{Introduction}

The growth of cross border investment in the world has been significant in recent years. One of the most salient features of today's globalization drive is cross border investments. Studies by Asiedu (2002), Furtan \& Holzman (2004) and Quazi (2007) see cross border investment as a key element of globalization that fill the gaps in the economic activities and investment profiles in transition, developing and emerging economies for economy recovery, growth and sustainable economy.

The International Monetary Fund (2015) and World Bank (2016) describe the concept of cross border investment as foreign direct investment that is a long-term investment reflecting a lasting interest and control, by a foreign direct investor (parent enterprise) of an enterprise entity resident in an economy other than that of the foreign investor and also as an investment that is made to acquire a lasting management interest, usually $10 \%$ of voting stock in an enterprise operating in a country other than that of the investors.

In today contemporary society, many countries are putting economic policy framework in place to retain foreign direct investors and to attract new ones because of its acknowledged advantages. Africa and Nigeria in particular have joined the rest of the world in seeking for cross border investments as a measure to boast economic and business activities in the major sectors of the economy. The UNCTAD World Investment Report (2018) shows that cross border investments inflow to West Africa is mainly dominated by inflow to Nigeria, who received $70 \%$ of the sub-regional total and $11 \%$ of Africa's total and out of this, Nigeria's oil sector alone receives $90 \%$ of foreign investment inflow, leaving the nonoil sector with insignificant foreign investment inflow.

At independence, Nigeria accounted for $16 \%$ and $43 \%$ of world cocoa and oil palm production respectively; the country was largely self-sufficient in terms of domestic food production (85 percent) and Nigerian agriculture contributed to over $60 \%$ GDP and 90\% exports; manufacturing was less than 3\% GDP and 1\% exports, while the oil sector represented only $0.2 \%$ GDP and less than $1 \%$ exports (UNCTAD 2009 and UNCTAD 2012). Ayodeji and Liu (2013) also notes that in 1960s, agriculture contributed up to $64 \%$ to the total gross domestic product (GDP) but gradually declined in 1970s to $48 \%$, further declined to $20 \%$ and $19 \%$ in 1980 and 1985 respectively, due to oil glut of the 1980s.

The rise in the world's oil prices and the macroeconomic policies of the Nigerian government, alongside the oil glut of 1980s led to 
over concentration of foreign investors in the oil and gas sector than other areas like gold mining, coal mining and even agro production that used to be the mainstay of the economy. Particularly, in the agricultural sector, cross border investment inflow is relatively low despite the host of agro resources that abound in different states of Nigeria for large-scale production, processing and packaging. At present, foreign affiliates in the Nigeria palm oil industry are few and have had no significant impact on the Nigerian economy compared to Indonesia and Malaysia, where palm oil production significantly contribute to over $45 \%$ GDP and $90 \%$ exports.

Objective of the Study. To examine the requisite factors influencing cross border investment inflow in the palm oil industry.

Research Hypothesis. There are key success factors that significantly affect investment inflow in the palm oil industry.

\section{Literature Review}

Several studies and reports have shown that over the years, the Nigerian extraction industry has attracted a lot of foreign investors and it has grown rapidly than any other industry to the extent of becoming the mainstay of the economy (Sachs \& Sievers, 2000; UNCTAD, 2009 \& 2012; Ayodeji \& Liu, 2013). The economy has remained largely dependent on oil and gas than any other natural endowed resource (Muhammad-Lawal \& Atte, 2006). Also, study conducted by UNCTAD (2018) observes that the Nigerian agricultural sector has been stagnated due to the emergence of oil as an important commodity in the world and the policy thrust of the government. MuhammadLawal and Atte (2006) uphold that besides oil, the major strength of the Nigerian economy is its rich agricultural resource base. These researchers in their school of thought argue that if these resources are effectively mobilized, the economic base will be diversified, over dependence on oil and imports will be reduced, domestic and foreign investments in agro production will flourish.

The Nigerian agricultural sector has vast areas of investment opportunities in palm oil production, cassava, corn, millet, sorghum and yam flour processing; cocoa, cashew, groundnuts, rice, rubber, forestry and livestock production. These investment potentials that lie within the shore of agricultural sector are beyond domestic investment. Agroindustry development which takes the forms of local and foreign investments promotes economic development of a developing or an emerging economy through the share of agriculture in the gross domestic product and contribution to foreign trade. Investment in the subunits of agriculture brings reform into the economy. To Aminu and Anono (2012), cross border investment in the agro-industry can generate employment opportunities, serve as source of foreign exchange earnings, provides the nation's industries with local raw materials and as a reliable source of government revenue.

Fasinmirin and Braga (2009) posit that the main reason for slow agricultural development in Nigeria is due to low level of investment in the agricultural sector necessitated by poor government involvement at the level of policy formulation and implementation. Theory and evidence show that there is poor business development in agro-based production, processing and packaging in Nigeria compared to what is obtained in other developing and emerging economies of the world like Indonesia, Malaysia, Thailand, Colombia, Uganda and Ghana. In the pursuit for agriculture economy recovery, Indonesia, Malaysia, Thailand, Colombia and Uganda have major foreign direct investors in palm oil production, whereas Ghana has major foreign investors in banana production/processing. Today, Indonesia and Malaysia are leaders of palm oil production in the world and they account for $85 \%$ of global palm oil production. Numerous foreign investors have also emerged in these countries that make use of palm oil by-products.

Justice (2012) avers that the availability of natural resources in most of the African countries calls for local and foreign investments. In the case of Nigeria, oil and agricultural sectors constitute the major proportion of natural resources that can contribute significantly to its economy. Cross border investment in agro production is concerned with international capital flow in which a firm in one country creates and expands a subsidiary in another country. Justice (2012) also observes that agricultural sector plays a distinctive role in the development of any economy. It is a source of food, which is essential in transition, developing, emerging and developed economies of the world; it contributes to the national income and provide employment.

ISSER (2007) avers that investment in agriculture significantly contributes to gross domestic product (GDP) and foreign exchange earnings. FARA (2006) and UN-DESA (2012) argue that despite the fact that agriculture remains a mainstay in many countries of the world; its contribution to gross domestic production (GDP) has declined in many regions of the world due to low investment and neglect of the sector. World Bank (2005) reports that in spite of 
the abundant natural and mineral resources, Nigeria has only gained very little in terms of cross border investment in agro-production compared to huge foreign investments in the oil and gas sector.

Hallam (2011) notes that cross border investments in the agro-industry go with a lot of benefits, ranging from capital inflows to technology transfer, high domestic productivity, production efficiency, improved product quality, employment creation, backward and forward linkages and integration. Justice (2012) posits that there is a multiplier effects through local sourcing of labour and other inputs, processing of outputs and increase in food suppliers for the domestic market and for export. Frimpong and Oten-Abayie (2008) opine that cross border investment promotes domestic investment through links in the production chain where foreign firms buy locally made inputs or supply intermediate inputs to local firms. The palm oil industry constitutes a significant part in a resource-based economy, providing food and raw materials for food, cosmetics, pharmaceuticals, plastics and bio-energy industries.

In making decisions to invest abroad, firms are influenced by a host of factors. Asiedu (2002) asserts that not all determinants are important to every investor in every location at all times. Some determinants may be more important to a given investor at a given time than to another investor. While it is difficult to determine the exact quantity and quality of cross border investment determinants that should be present in a location for it to attract a given level of inflow, a minimum of these determinants must be present before the inflow of cross border investments in a place.

Factor endowment brings about internationalization of firms. The natural and mineral resources account for high inflow of foreign direct investment in many African countries (Asiedu, 2006). According to UNCTAD (2004), 60\% of African's cross border investment is allocated to mineral resources and a number of African countries such as Angola, Nigeria, Cote d'Ivoire, Botswana and Namibia have been host to cross border investments in this direction.

Ekpo (2001) identifies economic, political, social and legal factors to be determinants of cross border investment. It is risky to invest in a political and economic hostile environment anywhere in the world. The extent at which these different environments exert influence determines the direction at which cross border investment strives in a host country. Sachs and Sievers (2000) posit that political and macroeconomic risks affect domestic and foreign business operations. Asiedu (2002) also notes that countries with high political and macroeconomic instability have high level of corruption. In a related study by Blonigen (2005), cross border investments do well in a host country having political and macroeconomic stability alongside large markets, natural resources endowment, good infrastructure, low inflation, an efficient legal system and a good investment framework.

Asiedu (2006) expresses that market size attracts cross border investments that are market-seeking. The stock of foreign direct investments is expected to be high for countries with large market size since market size is a measure of market demand. Importsubstituting investment flourishes in a host country with large market size. Erdal and Mahmut (2008), Bruce and Jeremy (2011) aver that cross border investment is higher in countries with larger and expanding markets and greater purchasing power, where firms can potentially receive a higher return on their capital and by implication receive higher profit from their investments.

Mishra, Mody and Murshid (2001) consider costs and skills of labour as important factors that can attract cross border investors. To them, labour cost effectiveness reduces cost of production, all factors remaining unchanged. The availability of cheap labour justifies the relocation of a part of the production process to foreign countries. Alongside labour cost, an investment firm is also concerned about the availability and quality of the labour force in line with new technology and the liberal employment policy which allows employment of expatriate staff to bridge the gap in the skill of local personnel.

Asiedu (2002) maintains that availability of good infrastructure is crucial for business development. The study argues that it stimulates the inflow of cross border investments in a host country. A study by Mishra, Mody and Murshid (2001) categorize infrastructure into physical and financial. The physical infrastructure centres on the availability of road, power and energy among others, whereas financial infrastructure is a well-developed financial market. Alfaro, Chanda, Kalemli-Ozcan and Sayek (2004), using cross section data, observes that poorly developed financial infrastructure can adversely affect an economy's ability to take advantage of the potential benefits of cross border investment. Jordaan (2004) claims that quality and well-developed infrastructure increases the productivity potential of investments in a country and therefore stimulates cross border investments inflow. Chenery and Strout (2006) in their study found out that problems related to funds mobilization were on the priority list of the factors discouraging investors in 
many Sub-Saharan African countries such as Nigeria, Uganda, Tanzania and Zambia.

The institutional environment is an important factor which directly affects business operations; it is an embodiment of factors that can promote or deter investment. Institutional environment covers the level of corruption and bribery in a place, which influences inflow of foreign investments and the cost of doing business in a host country; level of bureaucracy involved in establishing a business in a country; existence of incentives in the form of fiscal and financial attractions and the judiciary system in a host country, which is the key to protecting property rights and law enforcement regulations (Campos \& Kinoshita, 2003). Firm-specific advantages, location advantages, internationalization advantages, host country policies that actively target foreign investment, economic and structural reforms are other important factors influencing the inflow of cross border investment in a place. Also, new investors invest where there is high concentration of other foreign investors.

\section{Methodology}

The study used descriptive survey approach in estimating the relationship between key success factors and cross border investment inflow in the Nigerian palm oil industry.

Primary data were obtained through questionnaire instrument that satisfied the content validity and these data were drawn from respondents in foreign affiliate (IMC Limited) that is into palm oil production in Nigeria, One Stop Shop for Investors, Federal Ministry of Commerce, Trade and Industry, Federal Ministry of Agriculture and the Nigerian Institute for Palm Oil Research (NIFOR).

The study used Creative Research Systems Survey and E-sample Size Calculator in deriving the study's sample size of 276 respondents from a given population of 984 at $95 \%$ confidence level and 5\% confidence interval (margin of error). The sample size was validated through sample size table and Pearson Product Moment Correlation statistical tool was used for the data analysis.

\section{Model Specification}

The mathematical model that captured the response variable (cross border investment inflow) and the explanatory variables (key success factors), which the study focused on is expressed as:

$$
C B I_{(P O I)}=f\left(M S S+P D S+R O I+G F E+F M A+I M D+E L C+L U S+E D P+L R F \ldots+\mu_{t}\right)
$$

This is stated econometrically as:

$$
\begin{aligned}
& C B I_{(P O I)}=\beta_{0}+\beta_{1} M S S+\beta_{2} P D S+\beta_{3} R O I+\beta_{4} G F E+\beta_{5} F M A+\beta_{6} I M D+\beta_{7} E L C+\beta_{8} L U S+ \\
& \beta_{9} E D P+\beta_{10} L R F \ldots+\mu_{t}
\end{aligned}
$$

Where:

$\mathrm{CBI}_{\text {(PoI) }}=$ Cross Border Investment Inflow in Palm Oil Industry)

MSS = Market Size Structure

PDS = Product Demand Size

ROI $=$ Return on Investment

GFE $=$ GDP \& Foreign Earnings

FMA $=$ First Mover Advantage

IMD = Industrial Material Derivation

ELC = Effective Labour Cost

LUS $=$ Land Use Policy

EDP $=$ Economic Diversification Policy

$\mathrm{LRF}=$ Low risk factors

\section{Survey Results}

The survey results of the study from the field are presented below, showing the number of respondents and their percentages.
The table above is the Pearson Product Moment Correlation (PPMC) results of the regressor or input variables which are the explanatory or predictor variables of the study (key success factors) and the regress and or output variable of the study (investment inflow). At the 2-tailed test of the study variables, correlation is significant at 0.01 level. The $r$ value of 0.745 in the table indicated significant positive relationship between high market size and investment inflow.

The $0.729 \mathrm{r}$ value also explained that the intense demand nature of palm oil products for household and industrial use at the local and global market is a very strong factor that can significantly influence inflow of cross border investment. The analysis result of 0.796 $r$ value showed high return on investment (ROI) for willing investors in the industry. At the $r$ value of 0.652 , cross border investment in the Nigerian palm 
oil industry can significantly contribute to gross domestic product for the host country while both the host country and investors can significantly maximize high foreign exchange earnings.

Table 1 - Key Success Factors (KSF) in Palm Oil Investment Inflow

\begin{tabular}{|c|c|c|c|c|c|c|c|}
\hline $\mathbf{S} / \mathbf{N}$ & Questionnaire items & SA & $\mathbf{A}$ & $\mathbf{U}$ & SD & D & Total \\
\hline 1. & $\begin{array}{l}\text { High market size for prospective investors in the } \\
\text { Nigerian palm oil industry. }\end{array}$ & $\begin{array}{c}119 \\
\{43 \%\}\end{array}$ & $\begin{array}{c}147 \\
\{53 \%\}\end{array}$ & $\begin{array}{c}0 \\
\{0 \%\}\end{array}$ & $\begin{array}{c}3 \\
\{1 \%\}\end{array}$ & $\begin{array}{c}7 \\
\{3 \%\}\end{array}$ & $\begin{array}{c}276 \\
\{100 \%\}\end{array}$ \\
\hline 2. & $\begin{array}{l}\text { High market demand of palm oil products for } \\
\text { household and industrial use in today's Nigeria and } \\
\text { global markets for the investors. }\end{array}$ & $\begin{array}{c}132 \\
\{48 \%\}\end{array}$ & $\begin{array}{c}144 \\
\{52 \%\}\end{array}$ & $\begin{array}{c}0 \\
\{0 \%\}\end{array}$ & $\begin{array}{c}0 \\
\{0 \%\}\end{array}$ & $\begin{array}{c}0 \\
\{0 \%\}\end{array}$ & $\begin{array}{c}276 \\
\{100 \%\}\end{array}$ \\
\hline 3. & $\begin{array}{l}\text { High return on investment (ROI) earning for investors } \\
\text { willing to invest in the industry. }\end{array}$ & $\begin{array}{c}156 \\
\{57 \%\}\end{array}$ & $\begin{array}{c}104 \\
\{37 \%\}\end{array}$ & $\begin{array}{c}0 \\
\{0 \%\}\end{array}$ & $\begin{array}{c}11 \\
\{4 \%\}\end{array}$ & $\begin{array}{c}5 \\
\{2 \%\}\end{array}$ & $\begin{array}{c}276 \\
\{100 \%\}\end{array}$ \\
\hline 4. & $\begin{array}{l}\text { High earning of gross domestic product and foreign } \\
\text { exchange from the investment inflow. }\end{array}$ & $\begin{array}{c}76 \\
\{27 \%\}\end{array}$ & $\begin{array}{c}192 \\
\{70 \%\}\end{array}$ & $\begin{array}{c}3 \\
\{1 \%\}\end{array}$ & $\begin{array}{c}2 \\
\{1 \%\}\end{array}$ & $\begin{array}{c}3 \\
\{1 \%\}\end{array}$ & $\begin{array}{c}276 \\
\{100 \%\}\end{array}$ \\
\hline 5 . & $\begin{array}{c}\text { Early investors gaining first mover advantage as the } \\
\text { life cycle product in the industry is at the growing } \\
\text { stage. }\end{array}$ & $\begin{array}{c}122 \\
\{44 \%\}\end{array}$ & $\begin{array}{c}154 \\
\{56 \%\}\end{array}$ & $\begin{array}{c}0 \\
\{0 \%\}\end{array}$ & $\begin{array}{c}0 \\
\{0 \%\}\end{array}$ & $\begin{array}{c}0 \\
\{0 \%\}\end{array}$ & $\begin{array}{c}276 \\
\{100 \%\}\end{array}$ \\
\hline 6. & $\begin{array}{l}\text { Derivation of by-products as sources of raw materials } \\
\text { for industrial usage and for promotion of business } \\
\text { activities within and outside the industry. }\end{array}$ & $\begin{array}{c}175 \\
\{63 \%\}\end{array}$ & $\begin{array}{c}101 \\
\{37 \%\}\end{array}$ & $\begin{array}{c}0 \\
\{0 \%\}\end{array}$ & $\begin{array}{c}0 \\
\{0 \%\}\end{array}$ & $\begin{array}{c}0 \\
\{0 \%\}\end{array}$ & $\begin{array}{c}276 \\
\{100 \%\}\end{array}$ \\
\hline 7. & $\begin{array}{l}\text { Availability of labour and effective labour cost for } \\
\text { significant investment inflow. }\end{array}$ & $\begin{array}{c}86 \\
\{31 \%\}\end{array}$ & $\begin{array}{c}167 \\
\{61 \%\}\end{array}$ & $\begin{array}{c}2 \\
\{1 \%\}\end{array}$ & $\begin{array}{c}9 \\
\{3 \%\}\end{array}$ & $\begin{array}{c}12 \\
\{4 \%\}\end{array}$ & $\begin{array}{c}276 \\
\{100 \%\}\end{array}$ \\
\hline 8. & $\begin{array}{l}\text { Favourable government's policy on land use and its } \\
\text { accessibility for large scale agro production. }\end{array}$ & $\begin{array}{c}49 \\
\{18 \%\}\end{array}$ & $\begin{array}{c}201 \\
\{73 \%\}\end{array}$ & $\begin{array}{c}6 \\
\{2 \%\}\end{array}$ & $\begin{array}{c}7 \\
\{3 \%\}\end{array}$ & $\begin{array}{c}13 \\
\{5 \%\}\end{array}$ & $\begin{array}{c}276 \\
\{100 \%\}\end{array}$ \\
\hline 9. & $\begin{array}{l}\text { Government policy measures on economic } \\
\text { diversification. }\end{array}$ & $\begin{array}{c}124 \\
\{45 \%\}\end{array}$ & $\begin{array}{c}152 \\
\{55 \%\}\end{array}$ & $\begin{array}{c}0 \\
\{0 \%\}\end{array}$ & $\begin{array}{c}0 \\
\{0 \%\}\end{array}$ & $\begin{array}{c}0 \\
\{0 \%\}\end{array}$ & $\begin{array}{c}276 \\
\{100 \%\}\end{array}$ \\
\hline 10. & Low risk profile in the operational environment & $\begin{array}{c}0 \\
\{0 \%\}\end{array}$ & $\begin{array}{c}0 \\
\{0 \%\}\end{array}$ & $\begin{array}{c}0 \\
\{0 \%\}\end{array}$ & $\begin{array}{c}209 \\
\{76 \%\}\end{array}$ & $\begin{array}{c}67 \\
\{24 \%\}\end{array}$ & $\begin{array}{c}276 \\
\{100 \%\}\end{array}$ \\
\hline
\end{tabular}

Table 2 - Correlation Test

Dependent Variable: CBI

Independent Variables: KSF

Method: PPMC

Sample: 1-276

Observations: 276

\begin{tabular}{|c|c|c|c|c|c|c|c|}
\hline Variable & Constant & \multicolumn{2}{|l|}{ Sig. (2 tailed N) } & \multicolumn{2}{|c|}{ r-value Sig. Level } & \multicolumn{2}{|c|}{ Decision } \\
\hline MSS & 1 & 276 & $0.745^{* *}$ & 0.01 & Signific & $\mathrm{nt}(+)$ & \\
\hline PDS & 1 & 276 & & $0.729 * *$ & 0.01 & & Significant $(+)$ \\
\hline ROI & 1 & 276 & & $0.796 * *$ & 0.01 & & Significant $(+)$ \\
\hline GFE & 1 & 276 & & $0.652 * *$ & 0.01 & & Significant $(+)$ \\
\hline FMA & 1 & & 276 & & $0.536^{* *}$ & 0.01 & Significant $(+)$ \\
\hline IMD & 1 & 276 & & $0.866^{* *}$ & 0.01 & & Significant $(+)$ \\
\hline ELC & 1 & 276 & & $0.598 * *$ & 0.01 & & Significant $(+)$ \\
\hline LUS & 1 & 276 & & $0.705 * *$ & 0.01 & & Significant $(+)$ \\
\hline EDP & 1 & 276 & & $0.720 * *$ & 0.01 & & Significant $(+)$ \\
\hline LRF & 1 & 276 & & $0.351 * *$ & 0.01 & & Significant $(+)$ \\
\hline
\end{tabular}

** Correlation is significant at the 0.01 level (2-tailed). 
The $r$ value of 0.536 in the table implied that early investors in the industry will have significant first mover advantage. The $r$ value of 0.866 signified very strong positive relationship between palm oil by-products as sources of raw materials for industrial usage within and outside the industry and CBI inflow. In the case of availability of labour / effective labour cost and the CBI inflow, the $r$ value of 0.598 depicted fairly strong and positive relationship. The Pearson's $r$ value of 0.705 explained the high degree of relationship between government policy on land use/accessibility and CBI inflow. The analysis result of $0.720 \mathrm{r}$ value is a strong indication that government policy measures on economic diversification can significantly attract cross border investors in the palm oil industry while in the case of inherent risks in the operational environment, the $r$ value of 0.351 depicted that high risks in the operational environment is significantly associated with very low rate of inflow of cross border investors. Based on these results, the alternate hypothesis that key success factors significantly affect investment inflow in the palm oil industry is upheld.

\section{Discussion of Findings}

From the analysis results, some findings were made. The study found out that the presence of key success factors in a host country can attract cross border investors. The study also revealed that when these key success factors are down played in a host country, cross border investment inflow become highly insignificant. These findings are based on the results of test of hypothesis of the study that estimated the degree of significant relationship that exists between key success factor indicators in the palm oil industry and cross border investments inflow.

Thus, these findings agreed with the research results of Hallam (2011) and Justice (2012) that cross border investment has the advantage of efficient resource allocation, linkage effects, industrial productivity, multiplier effects on domestic/foreign market operations and high return on investment; Frimpong and Oten-Abayie (2008) that cross border investment promotes domestic investment through links in the production chain where foreign firms buy locally made inputs or supply intermediate inputs to local firms; FARA (2006), ISSER (2007) and UN-DESA (2012) that foreign direct investments in agriculture significantly contributes to gross domestic product and foreign exchange earnings.

Also, these findings are line with other research findings by Bruce and Jeremy (2011), Erdal and Mahmut (2008), Blonigen (2005), Jordaan (2004), Campos and Kinoshita (2003), Asiedu (2006), Mishra, Mody and Murshid (2001), Ekpo (2001), Sachs and Sievers (2000) that cross border investments do well in countries having political and macroeconomic stability alongside large market, labour cost effectiveness, adequate skills of labour, natural resources endowment, good infrastructure, effective legal system and sustainable investment policy framework.

\section{Conclusion and Recommendations}

Cross border investment has not had a meaningful impact in the Nigerian palm oil industry. The investment niche in the industry is what informed this study. The study found support that there are numerous prospects in this new area of strategic business unit. The study therefore recommends among others that government should seek for cross border investors in the palm oil industry and provide enabling environment and necessary conditions to boost business development in the industry. Also, to have a truly diversified economy for economic recovery, government should embrace cross border investment in the palm oil industry and other new strategic business areas that are beyond the oil and gas sector. Investment policies that are critical to the success of investment promotion in Nigeria should be reviewed by investment experts to enhance the nation's domestic and foreign investment profiles in all sectors of the economy.

\section{Contributions to Knowledge}

While several studies in Nigeria have mainly focused on cross border investment in the oil and gas sector, this present study has contributed to knowledge by examining new strategic business area outside the oil and gas economy for cross border investment inflow. The study has provided an investment niche platform in the palm oil industry that can be harness and used as baseline by other researchers and investment experts for further studies to re-examine the potentials in the Nigerian palm oil industry and for the government to redirect policies and action plan. Also, the findings of the study have provided an investment template for economy diversification in Nigeria. Thus, the implication arising from these contributions to knowledge is that investment in palm oil industry in Nigeria can be very rewarding both to the investors and the host country and it will significantly boost the economy. 


\section{References}

Ajuwon O.S., Ogwumike F.O. (2013) Uncertainty and foreign direct investment: A case of agriculture in Nigeria. Mediterranean Journal of Social Sciences, 4(1), 155-165.

Alfaro L., Chanda A., Kalemli-Ozcan S., Sayek S. (2004) FDI and economic growth: The role of local financial markets. Journal of International Economics, 64(1), 113-134.

Aminu U., Anono A.Z. (2012) An empirical analysis of the contribution of agriculture and petroleum sector to the growth and development of the Nigerian economy from 1960-2010. International Journal of Social Science and Education, 2(4), $758-765$.

Asiedu E. (2002) Determinants of foreign direct investment to developing countries: Is Africa different? World Development, $30(1), 107-119$

Asiedu E. (2006) Foreign direct investment in Africa: The role of natural resources, market size, government policy, institutions and political instability. The World Economy, 29(1), 63-77.

Ayodeji A.I., Liu Y. (2013) An evaluation and forecast of the impact of foreign direct investment in Nigeria's agriculture sector in a VAR environment. Journal of Economics and Sustainable Development, 4(10), 17-22.

Blonigen B.A. (2005) A review of the empirical literature on FDI determinants. Atlantic Economic Journal, 33, 383-403.

Bruce A.B., Jeremy P. (2011) Determinants of foreign direct investment. NBER Working Paper No. 16704. Cambridge: National Bureau of Economic Research.

Campos F.N., Kinoshita Y. (2003) Why does FDI go where it goes? New evidence from the transition economies. IMF Working Paper, 3/228.

Chenery H.B., Strout A. (2006) Foreign assistance and economic development. American Economic Review, 56, 680-733.

Ekpo A.H. (2001) Foreign direct investment in Nigeria: Evidence from time series data. CBN Economic and Financial Review, 35(1), 59-78

Erdal D., Mahmut M. (2008) Determinants of foreign direct investment flows to developing countries: a cross-sectional analysis. Prague Economic Papers, 4, 356-369.

FARA (2006) Framework for Africa agricultural productivity. Ghana: Forum for Agricultural Research in Africa.

Fasinmirin J.T., Braga F. (2009) Agriculture for sustainable food, energy and industrial development in the Sub-Saharan African: The case of Nigeria. African Journal of Food Science, 3(13), 429-433.

Frimpong J.M. and Oteng-Abayie, E. F. (2008). Bivariate causality analysis between FDI inflows and economic growth in Ghana, International Research Journal of Finance and Economics, 15, 103-112.

Hallam D. (2011) International investment in developing country agriculture: Issues and challenges. Food Security, 3(1), 91-98.

IMF Report (2015) Foreign private investment in developing countries. Washington D.C.

ISSER (2007) The State of the Ghanaian economy in 2006. Ghana: University of Ghana.

Jordaan J.C. (2004) Foreign direct investment and neighbouring influences. Unpublished doctoral thesis, University of Pretoria. Justice G.D. (2012) Effects of foreign direct investment inflows into agriculture on food security in Ghana. Journal of Economics and Sustainable Development, 3(2), 81-92.

Kenu J.L., Bekzhan F., Zhuldyz, S. (2015) The relationship between foreign direct investment, diversification and economic growth in natural resource oriented countries: Case of Kazakhstan. Journal of International Business and Economics, 3(2), 51-62.

Mishra D., Mody A., Murshid A.P. (2001) Private capital flows and growth. Finance and Development, 38(2), 1-6.

Muhammad-Lawal A., Atte O.A. (2006) An analysis of agricultural production in Nigeria. African Journal of General Agriculture, 2(1), 1-6.

Quazi R.M. (2007) Investment climate and foreign direct investment: A study of selected countries in Latin America. Global Journal of Business Research, 1(2), 1-13

Sachs J., Sievers S. (2000) FDI in Africa: Africa competitive report 1998. Geneva: World Economic Forum.

UNCTAD (2004) World investment report: Foreign direct investment and development, Geneva: United Nations.

UNCTAD (2009) Investment policy review: Nigeria. Geneva: United Nations.

UNCTAD (2012) Foreign agriculture investment country profile: Nigeria. New York: United Nations.

UNCTAD (2018) World investment report, transnational corporations, agricultural production and development. Geneva: United Nations.

UN-DESA (2012) Development strategy beyond 2015. Geneva: United Nations

World Bank (2016) External finance for developing countries. Washington, DC: World Bank. 